\title{
Community Property and Conflict of Laws
}

$T_{\text {HE old common law declared that the creation of interests in immova- }}^{\text {bles was governed by the law of situs, whereas mobilia sequnntur }}$ personam. This statement was applicable to the creation of interests in property by all of the varied methods practiced in an acquisitive society, including the securing of interests in property by marriage. Today, the common law is as certain as ever of its ground on the question of what law governs as to immovables-it is the law of the situs, just as of old. But the maxim as to mobilia has not sustained itself so well; the test of time has dealt hardly with it. As to many types of transactions today, the law declares that interests arise in movables wholly without regard to the domiciliary law of the parties; it is said that the law of the situs of the movable dealt with, at the time it is dealt with, is controlling, that practical necessity demands this result, both because of the desirability of having a readily ascertainable, mutually acceptable and immediately available rule of law to govern the transaction and because of the general irrelevance of the domiciliary law.

This modern trend away from the old maxim has not, however, been complete and all-including. The weight of authority still says that the distribution of a decedent's movable estate is controlled by the law of his last domicile. It still declares that the effect of the intermarriage of parties upon their mutual interests in previously owned movables is, in the absence of contract, governed by the law of the husband's domicile, or by that of the "matrimonial domicile." It has been supposed also that the same rule remained as to the creation of matrimomal property interests in movables acquired by a spouse after marriage, but the tendency to discard the old maxim has of late been carried into this area also. The practical merits of the old rule in operation, as compared with those of the suggested new one, nust be examined. Problems arising from removal of property and change of domicile from one state to another should also be considered at the same time. Differences between the law of community property states and the law of states retaining the common law rules as to matrimonial property give rise to most of the American litigation involving these issues.

\section{Donicile and Matrinontai Domicite}

Many of the cases involving the problem of acquisition of interests in property by reason of marriage refer the question directly to the law of the husband's domicile, but others speak of the law of the "inatri- 
monial domicile" as controlling. The concept of domicile as applied to an individual, whether he be husband or otherwise, has received much attention and is reasonably clear in the common law, ${ }^{1}$ but the term "matrimonial domicile" is less common. A good many cases, particularly in Louisiana and adjoining states, have used the tern as referring to the place intended by the parties as their domicile at the time they are married." It is obvious that "matrimonial domicile" so determined might be at a place at which neither of the new spouses was previously domiciled, at which neither of them had ever been, and to which they might not go for a considerable time in the future, if ever. That recogmition of a domicile so acquired, for any purpose at all, would be altogether contrary to all currently accepted notions of domicile and would defeat the very objects for which the law created the concept of domicile has been adequately pointed out by recent writers on the subject. ${ }^{3}$ Examination of the cases using the language indicated in regard to matrimonial domicile reveals that in all except one case ${ }^{4}$ the place settled upon as being the "intended domicile" was also the prior domicile of the husband.

It may fairly be said, then, that the so-called "matrimonial domicile," as a conception different from that of the liusband's domicile, has

1 Goodrich, Conflict of Laws (1927) 20; Conflict of Laws Restatement (Am. I. Inst. 1930) $\S \S 10-42$.

2 Le Breton v. Nouchet (La. 1813) 3 Mart. 60; Ford's Curator v. Ford (La. 1824) 2 Mart. N. S. 574; Allen v. Allen (La. 1843) 6 Rob. 104; Routh v. Routh (La. 1844) 9 Rob. 224; Fisher v. Fisher (1847) 2 La. Ann. 774; Percy v. Percy (1854) $9 \mathrm{Ia}$. Ann. 185; Kneeland v. Ensley (1838) 19 Tenn. (Meigs) 617; Texas v. Barrow (1855) 14 Tex. 179. There are many other cases using similar language. See Notes (1901) 85 Am. St. Rep. 552 ; (1903) 57 L. R. A. 353; cf. Latterner v. Latterner (1932) $121 \mathrm{Cal}$. App. 298, 301, 8 P. (2d) 870, 872. This language in the cases also finds expression in some textbooks. See McKay, Comarunity Property (2d ed. 1925) §622; 1 WHarton, Conflict of Laws (3d ed. 1905) §§ 192a, 196. Its wide circulation in this country is probably attributable to Story. STORY, CONFuTCT OF Laws (1st ed. 1834) §\$ 193-199.

3 Goodrich, Matrimonial Domicile (1917) 27 Yare L. J. 49; Harding, Matrinronial Domicile and Marital Rights in Movables (1932) 30 MICE L. REv. 859.

${ }_{4}$ Texas v. Barrow, supra note 2 . In this case, a husband and wife domiciled in Mississippi decided to move to Texas, going by way of Tennessee to visit the wife's relatives. In Tennessee an uncle gave the wife a slave as a gift. They took the slave to Texas with them. By Tennessee law the slave would be the husband's property; by Texas law it would be the wife's separate property. In deciding who owned the slave by the common test of reference to the law of the domicile, the Texas court held that the intent of the spouses to settle in Texas, existent at the time the wife received the slave, even though they had not yet come to Texas, caused Texas to be the "matrimonial domicile," so that the slave from that time on was the wife's separate property by Texas law. Professor Goodrich, loc. cit. supra note 3 , undertakes to show that Texas v. Barrow is not really in point, because the same result could have been reached by the law of the old doinicile, Mississippi. The fact remains that the Texas court said that it was referring not to Mississippi law but to Texas law. 
no effect upon the property rights of the spouses. The standard rule is that the wife's domicile is at the husband's, she not being justifiably separated from him. And the husband's domicile cannot change to a new place by mere intent that it do so, without more. ${ }^{5}$

\section{Nuptial Contracts, INTPLIEd AND Express}

The problems suggested by the famous Enghish cases of De Nicols v. Curlier $^{6}$ and In re De Nicols ${ }^{7}$ must be noticed briefly. These cases held that a French couple celebrating their marriage in France, without any express ante-nuptial contract in relation to after-acquired property, would be deemed to have entered into such a contract nevertheless, the terms of the inplied contract being the provisions of French law applicable to the property of persons marrying without an express property contract.

That the imphication of such a contract would be altogether unreal and inproper as between the ordinary American bride and groom is quite evident. Usually they are not thinking about property at all, at least not about future acquisitions. Changes in domicile are so frequent, so constantly contemplated by so many people, that it would be the height of artificiality to say that every couple on marriage intend always to attach to their union forever the inarital property laws of the domicile for the time being. As to marriages entered into by parties domiciled in American states, such inplied contracts have never been set up. ${ }^{8}$ Whether there is really such a contract in the case of a French marriage is another question-and it would seem in an American court to be a question of fact as to whether the admittedly controlbing French law treats the transaction as amounting to a contract. ${ }^{9}$ Of course, the local public policy of an American forum might prevent the enforcement of this type of contract, even if it were found to exist.

An express nuptial contract specifying what marital interests shall exist in after-acquired property is valid and is entitled to the same

5 Authorities cited in note 1 , supra.

6 [1900] A. C. 21 (dealing with after-acquired English movables).

7 [1900] $2 \mathrm{Ch} .410$ (dealing with after-acquired English land).

8 The leading American case on this point is Saul v. His Creditors ( $\mathrm{La} .1827$ ) 5 Mart. N. S. 569 . This case, though actually decided by reference to early Spanish law, is in its result so consonant with American common law ideas that it has been altogether accepted, despite an opinion based on authorities utterly strange to common lawyers. Its following is in the literally hundreds of American cases holding that marital rights in property acquired after change from a first domicile are controlled by the law of the situs of the property thus acquired or by the law of the domicile at the time of the acquisition, and not by the law of the abandoned first domicile. See notes 41,44 , infra.

8 Conflict of Laws Restatrarent (Am. L. Inst. 1932) §353. Probably no such imphed contract is discoverable, even by French law, in relation to all property afterwards acquired, everywhere. In re Majot's Estate (1910) $199 \mathrm{~N}$. Y. 29, 92 N. E. 402, 29 L. R. A. (N.s.) 780; Note (1910) 10 CoL. L. REv. 147. 
enforcement as any other valid contract. A separate problem of interpretation of the contract exists, however, and some courts are quite ready to interpret the contract as not covering the new conditions produced by acquisition of property at a new domicile. ${ }^{10}$ Broadly speaking, the contract should be quite specific in its reference to "all afteracquired property, wherever acquired, regardless of domicile"; else it is apt to be interpreted as inapplicable. ${ }^{11} \mathrm{~A}$ few cases have used language indicating that such contracts might be more readily interpreted to apply to after-acquired movables than to immovables. If the problem is really one of interpretation of an admittedly valid contract, and not one of the enforceability of the contract in the light of local public policy, it is difficult to see how this distinction can logically be taken. ${ }^{12}$

\section{Property Owned at Tima of Marriage}

The question of what law controls the interests of each spouse in property of the other owned at the time of the marriage is reasonably well settled. As to immovables there is no doubt; the law of the situs controls. The point is so elementary that it is seldom raised in the cases.13 And, of course, an express pre-marital contract would control as to either movables or immovables. ${ }^{14}$ The American cases as to unovables are almost as unanimous in their results as are those which deal with land. The law of the husband's domicile at the time of the marriage determines what interests arise by reason of the marriage in movables then owned by either spouse. ${ }^{15}$ Several cases, instead of saying that the law of the husband's domicile is controlling, reacl the same result by referring the question to the so-called "matrimonial domi-

10 Besse v. Pellochoux (1874) 73 Ill. 285; Long v. Hess (1895) 154 Ill. 482, 40 N. E. 335 ; Castro v. Tllies (1858) 22 Tex. 479; Fuss v. Fuss (1869) 24 Wis. 256. For cases in which the contract was deemed to cover the new conditions at the new place and time, see Sanger v. Sanger (1931) 132 Kan. 596, 296 Pac. 355; Murphy v. Murphy (La. 1817) 5 Mart. 83; Kleb v. Kleb (1905) 70 N. J. Eq. 305, 62 Atl. 396; Decouche v. Savetier (N. Y. 1817) 3 Johns. Ch. 190; Scheferling v. Huffman (1854) 4 Ohio St. 241. For general discussion, see Note (1932) 27 Irr. I. REv. 202.

11 See MCKAY, op. cit. supra note $2, \S 626$.

12 See Notes (1930) 43 HARv. L. Rev. 1286; (1932) 27 IrL. L. REv. 202.

13 Goodrich, op. cit. supra note 1 , at 273 ; MinOR, Conflict of LAws (1901) 173; Story, op. cit. supra note 2, at 268; Conflict of Laws Restatement (Am. L. Inst. 1932) $\$ 257$.

14 Cases cited in note 10, supra. Implied contracts such as were discovered in the De Nicols and Curlier cases, would, of course, be controlling also, but the confusing consequences of such contracts are avoided in America by rejection of the doctrine of those cases. See note 8, supra.

15 Goodrace, op. cit. supra note 1, at 275 ; MINor, op. cit. supra note 13 , at 175; StoRy, op. cit. supra note 2, at 267; Conflict of LAws RestateMENT (Am. L. Inst. 1932) §310. 
cile."18 The sameness of result follows from the fact that in no discovered case involving pre-marital property has the "matrimonial domicile" been found to be other than the husband's domicile at the time of inarriage. ${ }^{17}$

It is arguable that the law of the situs of each piece of movable property, rather than the law of the husband's domicile, should determine what interests arise in the movable on marriage. Undoubtedly, a state does have a sort of primary control over all property, movable as well as immovable, properly within its borders. As to such property it can if it wishes refuse to let the law of the domicile control. One or two states have done that as to intestate succession to movable property. They have refused to follow the generally accepted rule that intestate succession to movables is controlled by the law of the decedent's domicile at death and have insisted that their own law, as that of the situs, must control. ${ }^{18}$ The only reason for following the domiciliary law, rather than that of the situs, in either case, is one of convenience-the desirability of having a single clear and readily applicable rule for determining interests in what is really one body of property, however scattered it be. The logic which requires that the law of the situs be controlling is satisfied by saying that the law of Conflict of Laws of the situs refers the problem to the law of the domicile, as reasons of convenience require that it should do. That the law of the state of situs is not absolutely compelled to make this reference is shown by the Missouri case of Locke v. McPherson. ${ }^{19}$ About all that can be said of that case is that Missouri, being the situs of movables owned by the bride when she married, had the power to decide that its own law, and not the law of the husband's domicile, New York, should determine what rights the latter acquired in the bride's movables, and it so decided. Though no very intelligible reasons were stated by the court for its departure from the general rule, it was obviously giving weight to a local public pohicy favoring the liberal Missouri Married Women's Property Act as against the old common law rule, still operative in New York, which practically gave a married woman's movables to her husband. Such a decision cannot be said to be improper, but it is unusual.

\section{Removal of Property into ANother State}

A more searching problem now presents itself. Suppose that a husband and wife, douniciled in a common law state, there own movables

${ }^{10}$ Fisher v. Fisher; Percy v. Percy, both supra note 2; see STORY, op. cit. supra note 2 , at 267,271 .

17 Texas v. Barrow, supra note 2 , involved property acquired after marriage.

18 See Ir.. Rev. Stat. AnN. (Smith-Hurd, 1929) c. 6, \$7; ibid. c. 39, \$1; MIss. Code ANN. (1930) §1401; Goodrich, op. cit. supra note 2, at 368.

19 (1901) 263 Mo. 493, 63 S. W. 726, 52 L. R. A. 420. 
which by the law of that state, their domicile and the situs of the movables, are the husband's property. They then remove the goods to another state, in which state the goods would have been community property if first acquired or held there. Or suppose that the first domicile and situs are in the community law state, that the movables there were commumity property, and that the later removal is to a common law state. Does the character of the ownership of the goods change in either case by reason of the removal?

It is quite clear that, at common law, it does not. The specific problem has been presented many times, and the cases have all reached the same result, both where separate property had been taken into community property states ${ }^{20}$ and where community property had been taken into common law states. ${ }^{21}$

This rule that pre-existent marital interests persist after removal does not always work out as fairly in practice as might at first thought be expected. The community property system, roughly speaking, serves the same function as do dower and curtesy under the common law. So, if a husband dies domiciled in Massachusetts, owning property, his widow has a dower interest therein. But if, a year before his death, he removed his domicile to a community property state, taking his property with him, then died, the law of the latter state would not treat him

20 Dye v. Dye (1858) 11 Cal. 163; Kraemer v. Kraemer (1877) 52 Cal. 302 ; In re Estate of Burrows (1902) $136 \mathrm{Cal} .113,68 \mathrm{Pac}$. 488; In re Estate of Nicholls (1912) $164 \mathrm{Cal} .368,129$ Pac. 278; In re Estate of Warner (1914) $167 \mathrm{Cal} .686$, 140 Pac. 583; In re Estate of Boselly (1918) 178 Cal. 715, 175 Pac. 4; In re Estate of Arms (1921) 186 Cal. 554, 199 Pac, 1053; In re Estate of Frees (1921) $187 \mathrm{Cal}$. 150, $201 \mathrm{Pac} .112$; In re Estate of Nickson (1921) $187 \mathrm{Cal} .603,203$ Pac. 106: In re Estate of Drishaus (1926) 199 Cal. 369, 249 Pac. 515; Brunner v. Title Ins. \& Trust Co. (1914) 26 Cal. App. 35, 145 Pac. 741; Williams v. Sutphen (1928) 92 Cal. App. 697, 268 Pac. 946; In re Bruggemeyer's Estate (1931) 115 Cal. App. 525, 2 P. (2d) 534; Melvin v. Carl (1931) 118 Cal. App. 249, 4 P. (2d) 954, Sup. Ct. hearing den., Jan, 7, 1932; Scott v. Remley (1931) 119 Cal. App. 384, 6 P. (2d) 536; Latterner v. Latterner, supra note 2; In re Thornton's Estate (1932) 69 Cal. App. Dec. 1195, 12 P. (2d) 674; Stephen v. Stephen (1930) 36 Ariz. 235, 284 Pac. 158; Douglas v. Douglas (1912) 22 Idaho 336, 126 Pac. 772; Tanner v. Robert (La. 1826) 5 Mart. N. S. 255; Slocomb v. Breedlove (1835) 8 La. 143; Young v. Templeton (1849) 4 La. Ann. 254; Bosma v. Harder (1919) 94 Ore. 219, 185 Pac. 741; Oliver v. Robertson (1874) 41 Tex. 422 ; McDaniel v. Harley (Tex. Civ. App. 1897) 42 S. W. 323; Blethen v, Bonner (1902) 30 Tex. Civ. App. 585, 71 S. W. 290; Thayer v. Clarke (Tex. Civ. App. 1903) 77 S. W. 1050; Elliott v. Hawley (1904) 34 Wash. 585, 76 Pac. 93; Brookman v. Durkee (1907) 46 Wash. 578, 90 Pac. 914, 13 Ann. Cas. 839, 12 I. R. A. (N.s.) 921; Witherill v. Fraunfelter (1907) 46 Wash. 699, 91 Pac. 1086; Meyers v. Albert (1913) 76 Wash. 218, 135 Pac. 1003; Myers v. Vayette (1927) 146 Wash. 1, 261 Pac. 647; In re Gulstine's Estate (1932) 166 Wash. 325, 6 P. (2d) 628.

21 These cases are of course fewer in number, but quite as clear in their holdings. Depas v. Mayo (1848) 11 Mo. 314; Edwards v. Edwards (1925) 108 Okla. 93, 233 Pac. 477; cf. Doss v. Caunpbell (1858) 19 Ala. 590, Beard's Ex'r v. Basye (1846) $46 \mathrm{Ky}$. (7 B. Mon.) 133; Avery v. Avery (1854) $12 \mathrm{Tex} .54$. 
as leaving community property, nor would that state have any law of dower applicable to such a situation. That state being the domicile of the decedent at death, and he dying intestate, its law would give the whole estate, as the husband's separate property, to his heirs and next of kin, and the widow might receive nothing. That result would defeat the spirit both of the dower laws of Massachusetts and of the community property laws of the distributing state; yet it would be reached none the less. The trouble is that the incidents of separate property ownership in California, for example, are in many respects not the same as those of the same ownership in Massachusetts. The law's insistence that property interests be not divested by renoval across state lines actually results in the elimination of certain very important incidents of the prior ownership.22

The law has, however, consistently maintained the distinction between actual ownership and nere incidents of ownership, such as dower, curtesy, exemptions from attachment, homestead, and the like. Actual ownership is regarded as a vested right, the sort of thing that is protected by the due process clause of the Federal Constitution; ${ }^{23}$ mere incidents of ownership receive no such protection, and are subject to whatever law happens to be applicable to the property at the time the incident of ownership is sought to be exercised.

As an original question it might well be doubted whether the interest of one spouse in marital property, as opposed to the interest of the other spouse therein, slould be treated as a vested right at all. ${ }^{24}$ Increasing legal recognition of the separate individualities of spouses, and the ease with which modern divorces can be secured, furnish strong argument, lowever, for the conclusion that substantial separate interests should exist in marital property. At any rate, the courts have recognized such interests as actually separate, for many purposes, and have treated them as vested interests which may not under the due process clause be arbitrarily defeated or disregarded. So, the separate interests of spouses in community property have been held to be such vested estates that separate federal income tax returns on the profits therefrom may be insisted upon by the spouses. ${ }^{25}$ The sane result has been

22 This fact probably induced the enactment of the California statute quoted in note 61 , infrat, and discussed in the accompanying text.

23 U. S. Const., Amend. XIV.

${ }^{24}$ See Daggett, Modern Problem of Nature of Wife's Interest in Community Property-A Comparative Study (1931) 19 CAIIF. L. Rev. 567, for the view that the wife's interest in community property is only an expectancy, and not a real present title to the property, whereas the husband's interest represents the present ownersbip.

25 Poe v. Seaborn (1930) 282 U. S. 101 (Washington community property); Goodel v. Koch (1930) 282 U. S. 118 (Arizona comununity property); Hopkins v. Bacon (1930) 282 U. S. 122 (Texas community property); Bender v. Pfaff (1930) 
reached in cases involving attempts by statute to change pre-existent marital interests in property, or to subject to inheritance taxation that part of the community estate remaining to the surviving spouse. ${ }^{20}$ In view of this general judicial attitude as to the vested nature of marital property, any attempt by any state to abrogate the general rule and provide instead that mere removal into the state should change the character of marital ownership of property so removed would probably be held to be unconstitutional. ${ }^{27}$

But what may happen if, after removal, the property brought into the new state is used in the acquisition, by purchase or exchange, of new property in the new state? More than half of the numerous cases cited $^{28}$ for the proposition that there is no change in marital interests by removal alone apply also to the case now supposed and declare that the newly acquired property is held in the same character of ownership as that with which it was acquired. This is true whether the newly acquired property is land or movables. Most of the cases purport to base this result altogether on principles of the law of Conflict of Laws. It seems wholly clear, however, that two entirely distinct legal principles are involved in such cases, and that separation of them is important.

It is the law in practically every American state that property purchased with separate property is itself the separate property of the one whose property paid for it, and property purchased with community property is itself community property or joint property. In a community property state this is true both at law and in equity; ${ }^{20}$ in a common law state it is true in equity, the preservation of the interest of the one out of possession being most frequently accomplished by resulting trusts. ${ }^{30}$ The legal principle here referred to has been called the

282 U. S. 127 (Louisiana community property); United States v. Malcolm (1931) 282 U. S. 792 (California community property); cf. Hoeper v. Tax Comm. of Wis. (1931) 284 U. S. 206.

26 Spreckels v. Spreckels (1897) 116 Cal. 339, 48 Pac. 228, 58 Am. St. Rep. 170, 36 L. R. A. 497; In re Estate of Drishaus; In re Bruggemeyer's Estate, both supra note 20; Dixon v. Dixon's Ex'rs (1832) 4 La. 188; cf. Brookman v. Durkee, supra note 20 . Such marital interests receive the protection of the state constitutions involved as well as of the Federal Constitution.

27 See Conflict of Laws Restatement (Am. L. Inst. 1932) \$280. This at least partially explains the holdings that the California statute, discussed in notes 61 ff. infra, is unconstitutional. See In re Estate of Drishaus; In re Bruggemeyer's Estate, both supra note 20. That statute involves other probleins, however, than the removal of property into the state.

28 Cases cited in notes 20-21, supra.

29 McKay, Communty Property (2d ed. 1925) §§405-424; Jacob, Law of Community Property in Idaho (1931) 1 IDaEo I. J. 1, 36; Note (1924) 12 CaLIf. L. REv. 124.

30 Cases cited in note 21, supra; Bogert, Trusts (1921) 113 ; 1 Perry, Trusts and Trustees (7th ed. 1929) 183, 233; 3 Pomerox, Equity Jurisprudence (4th ed. 1918) §§ $1031 \mathrm{ff}$. 
"source doctrine." 31 The "source doctrine" under the law of any given state is equally applicable to property acquired with other property just brought into the state, and to property acquired with other property which has been in the state all along. Thus we see the two principles separately presented. First, goods brought into the state are subject to exactly the same marital interests of ownership as existed at the prior situs. That is a rule of Conflict of Laws, probably backed up by the due process clause of the Federal Constitution. Second, by purely local law, the rule represented by the "source doctrine" causes the old marital property interests to reappear in new property acquired therewith. That rule has nothing at all to do with the law of Conflict of Laws; it is a part of the Law of Property of the state in which the transaction occurs.

It is entirely possible, however, that the "source doctrine" may cease to represent the law of some particular state. For example, California might enact a statute declaring to be community property any property purchased in Califorma by a California domiciliary with other property which would have been community property had it been first acquired in California by a California domiciliary. Such a statute unight be constitutional. Certainly this is true: If California can constitutionally say that property purchased with separate property which has always been California property shall become community property, it can say the same thing as to property purchased with separate property recently brought in from elsewhere. The point is that after goods are brought into Califronia, with pre-existent ownerships persisting, the goods become wholly subject to California law. The only question which can then remain is as to the constitutionality of the admittedly apphicable California law. ${ }^{32}$ The same thing is obviously true of commumity property taken into a common law state. When it arrives in Arkansas from Louisiana, for example, the joint interest remains. Thereafter, Arkansas law controls it. Probably new dealings with the property in Arkansas will merely cause the old joint interests to reappear in new goods, under the so-called "source doctrine." But it is possible that new dealings with the property will cause the old interests to disappear, if the Arkansas law so provides and is constitutional. That such law might well be constitutional is suggested by the old cominon law rule, undemiably constitutional, that choses in action and possibly other personalty which had been the separate property of the wife be-

31 Jacob, loc. cit. supra note 29.

32 Cf. Brookman v. Durkee, supra note 20. 
came the husband's on his act of reducing them to possession. ${ }^{33}$ It is hard to see how such a rule of law would be any less constitutional today, either as applied to the wife's movables already situated in the state having the rule, or as applied to the wife's interest in community property just brought into the state.

\section{Property Acoutred After Marriage}

If immovable property be acquired after marriage, there is no doubt that, in the absence of a controlling nuptial contract, ${ }^{34}$ the law of the situs determines what marital interests exist in it. ${ }^{35}$ The unanimous rejection in the American courts of the doctrine of implied contract, represented by the De Nicols and Curlier cases $^{36}$ assures that result. As to movables, the American rejection of that doctrine also serves to exclude one possibly controlling law, that of the domicile at marriage, in cases $\mathrm{m}$ which there is a later change of domicile prior to acquisition of the movables in question. The choice, therefore, lies between the law of the situs of the moveables at the time they are acquired, and the law of the domicile of the spouses, i.e., the husband's domicile, at that time.

It must be remembered, whichever law be chosen, that the situs has a sort of primary control over property within its borders. ${ }^{37}$ The situs can refer the determination of marital interests in the movable to the law of the domicile, or it may determine the matter by its own law, as it pleases. For example, between 1828 and 1852, the cominunity property law of Louisiana was made to apply only to property of persons celebrating their marriage in Louisiana or afterwards becoming domiciled in Louisiana. ${ }^{38}$ So, today the Louisiana community property statutes are expressly applicable to all property, movable or iminovable, acquired in Louisiana by non-residents. ${ }^{3 \theta}$ This primary dominance of the situs is also illustrated by courts which announce a general rule that the law of the husband's domicile governs, yet occasionally apply their own law to movables situated in their jurisdiction if the particular domiciliary law is in some way opposed to a strong local public policy of the

33 Copeland v. Jordan (1918) 147 Ga. 601, 95 S. E. 13; Miller v. Keown (1917) $176 \mathrm{Ky} .117,195 \mathrm{~S}$. W. 430; see Madden, Persons and Domestic Reiations (1931) 85; 1 Schodler, Marriage, Separation, Divorce and Doscestic RELATIONS (6th ed. 1921) \$157.

34 Cases cited in note 10 , supra.

35 Authorities cited in note 13, supra.

${ }^{36}$ Supra notes 6, 7.

37 Authorities cited in notes 18,19 , supra, and accompanying text.

38 Conner v. Elliott (1855) 59 U. S. (18 How.) 591; Succession of Packwood (La. 1845) 9 Rob. 438; Succession of Packwood (La. 1845) 12 Rob. 334.

${ }^{39}$ LA. Rev. Code (Merrick's 3d ed. 1925) art. 2400. But cf. Williams v. Pope Mfg. Co. (1900) 52 La. Ann. 1417, 27 So. 851. 
forum. ${ }^{40}$ Such statutes and decisions as these, however, do not necessarily represent either what the general rule is or what it should be; they may represent rather the occasional exercise of an ordinarily unused power.

In fact, the great body of American case authority is to the effect that the law of the domicile, rather than that of the situs at the time of acquisition, controls. ${ }^{41}$ Practically all leading writers on Conflict of Laws take the same position. ${ }^{42}$ But there is some authority the other way. The most impressive is that of the American Law Institute's Restatement of Conflict of Lawes. ${ }^{43}$ Two cases have been discovered which lend support to the view that the law of the situs governs, but the strength of these cases is lessened by the fact that other reasons for the result reached existed in each case and were in each case relied upon by the court. ${ }^{44}$ Also, the minority view is upheld by some recent writ-

${ }_{40}$ Smith v. McAtee (1867) 27 Md. 420, appears to be a case of this type; cf. Newcomer v. Orem (1852) 2 Md. 297. Locke v. McPherson, supra note 19, is a case of the same general type.

41 Nelson v. Goree's Adm'r (1859) 34 Ala. 565; Birmingham Waterworks Co. v. Hume (1898) 121 Ala. 168, 25 So. 806; Dye v. Dye, supra note 20; Hicks v: Pope (1835) 8 La. 554; Succession of Packwood (two cases), supra note 38; cf. Succession of McKenna (1871) 23 La. Ann. 369; Newcomer v. Orem, supra note 40; Kneeland v. Ensley, supra note 2; Muus v. Muus (1882) 29 Minn. 115; McLean v. Hardin (1857) 56 N. C. (3 Jones Eq.) 294; Erdington v. Mayfield (1849) 5 TEX. 363; Texas v. Barrow, supra note 2; Colpe v. Lindblom (1910) 57 Wash. 106, 106 Pac. 634; Snyder v. Stringer (1921) 116 Wash. 131, 198 Pac. 733. The same rule is announced in scores of other cases, though in many of the others the places of situs and domicile coincided, so that statement of the rule amounted to no more than dictum.

Louisiana cases here cited, decided between 1828 and 1852, are not necessarily rendered out of point on the point for which they are here cited by the then Louisiana statute inaking the counmunity system inapplicable to non-residents. Cases cited in note 38, supra. The Louisiana courts still had to decide whether the non-commumity law of the situs, Louisiana, or the law of the domicile, should govern. And of course the special Louisiana rule did not affect the case where the situs was elsewhere and the domicile was in Louisiana.

42 GoODRICE, op. cit. supra note 1 , at 277 (Goodrich does, however, at page 280, indicate some uncertainty on the poimt.); MuNoR, op. cit. supra note 13, §81; STORY, op. cit. supra note 2 , §§ 186-187; 1 WHARTON, op. cit. supra note 2, $\S \S 192 a, 196$.

43 Section 311 reads as follows: "An mterest in movables acquired by either or both of the spouses during coverture is in one or the other, or both, according to the law of the place where the movables are situated when it was acquired." A special note is appended to the section, recognizing the authorities to the contrary.

44 Shumway v. Leakey (1885) 67 Cal. 458, 8 Pac. 12 (law of situs presumed to be same as that of forum); Gooding Mill \& Elevator Co. v. Lincoln Co. Bank (1912) 22 Idaho 468, $126 \mathrm{Pac}$. 772 (result supported by findings of estoppel and 'of gift, as well as by holding on conflict of laws point); cf. Smith v. McAtee, supra note 40 . 
ers in the law reviews. ${ }^{45}$ It is clear that the overwhelming weight of case authority against the view taken by the Restatement does not conclude the issue. The opposing views must be dealt with on their merits.

One point certain to be raised against the view that the law of the domicile governs is its ancestry. Presumably, it is one of the numerous children of that promiscuous parent, the maxim mobilia sequuntur personam. Of course, the idea that a chattel has no situs other than the domicile of its owner is absurd. In the case of tangible chattels, that situs is a very real and inescapable fact, and undoubtedly by its law governs as to most creations and transfers of interests in such chattels. Most of the authorities have said, however, that the situs does not govern as to unarital interests, and the present task is to disregard ancestry entirely, and determine whether the practical advantage to be gained by choosing the law of the situs rather than that of the domicile as controlling justifies the overturning of the present authorities.

Now, it has sometimes been supposed that allowing the law of the situs to govern marital interests would cause tremendous confusion, because married persons are apt to acquire chattels by purchase, in dozens of different states, and to move those chattels about, so that it would be well-mgh impossible to determine at some later period what interests exist in the chattels by the laws of the various places of original acquisition. Actually this difficulty would not frequently arise. The money or other property with which all these purchases are made would usually come from some single place, probably the domicile, by whose law its ownership was clearly settled as separate in one or the other of the spouses, or as community, and the character of ownership in the purchasing goods would re-express itself uniformly in the goods purchased, wherever they were purchased or later removed. Of course, the "source doctrine" does not have to be law in every state, and perhaps is not law in some states under some circumstances; nevertheless it is law and is applicable to almost all of such transactions in most states, and does practically operate to cause unarital interests in scattered movables to exist in accordance with the law of some single state, usually the domicile.

There are some cases, however, to which the "source doctrine" is not applicable, and to these we must direct our inquiry. Snyder $v$. Stringer ${ }^{46}$ presents the problem well. There, $H$ and $W$, husband and

$45 \mathrm{Jacob}$, op. cit. supra note 29 , at 26 , declares that in Idaho the law of the situs controls under these circuunstances. The holding in Gooding Mill \& Elevator Co. v. Lincoln Co. Bank, supra note 44, indicates that this conclusion is correct. But see Douglas v. Douglas (1912) 22 Idaho 336, 342, 125 Pac. 796, 797. Harding, op. cit. supra note 3 , at 868 , presents an argument on principle in favor of the law of the situs.

46 Supra note 41 . 
wife, were domiciled in Washington, by whose law the community property system prevails. Then $H$ earned money in Montana and Iowa, and with it bought an automobile in Iowa, which he brought home to Washington. By Montana and Iowa law, such acquisitions would be $H$ 's separate property. A separate creditor of $H$ levied on the automobile in Washington, but the levy was set aside, the court holding that the law of the domicile at the time of acquisition made $H$ 's earnings, therefore the automobile purchased with his earnings, community property.

It is submitted that this result is not only supported by the overwhelming weight of authority, ${ }^{47}$ but is a socially desirable result. The facts of the case illustrate the clear tendency of movables acquired at various and scattered places to move physically to the domicile. The ordinary person may acquire property at many different places. This is particularly true of persons living in cities near state borders, such as Newark or Jersey City, New Jersey, or Kansas City in both Missouri and Kansas, or Texarkana in both Texas and Arkansas. The movable property of such persons is usually collected physically at one place, the domicile; after it is originally acquired at various places, the acquirer will take it home with him.

That means that disputes in regard to the ownership of the property and marital interests therein will most frequently arise at the domicile. Naturally, parties engaging in such disputes, lawyers to whom the disputes are referred, and jndges before whom they are litigated will be more familiar with the law of the domicile than with that of the place or various places of original acquisition. ${ }^{48}$ Convenience in the sense of ready access to knowledge of the controlling law, if nothing else, would therefore favor allowing the law of the domicile to govern.

Furthermore, it seems that the convenience and desirability of having the whole movable estate of the spouses governed, as to marital interests therein, by one uniform body of law is as conpelling with property acquired after marriage as with property existent at the time of marriage..$^{49}$ Examination of the cases shows that most of the litigation in regard to marital property interests arises in connection with distribution of the property on death or division of the property after

47 Cases cited in note 41 , supra.

48 Examination of the seventeen cases cited in notes 41,44 , supra, in which situs of acquisition and domicile were at different places, shows that in eleven cases action was brought at the domicile at time of acquisition, in three cases the facts were not clear, while in the remaining three action was brought at a place other than the domicile. In two of these three, however, the property in question was in choses in action, which cannot fairly be said to have any situs. See notes 56,57 , infra.

49 See Note (1930) 43 Harv. L. Rev. 1286. 
divorce. ${ }^{50}$ In such cases it would obviously be difficult and laborious to trace each bit of movable property to the place of its original acquisition, to determine what marital interests in the movable were created by the law of such place. Division or distribution of the property in accordance with a fair system of law is the most that can be asked for in any event. That being true, it seems that the great convenience of dealing with a single system of law, so that the whole of the movable property could be divided or distributed in accordance with a single legal basis of ownership, ${ }^{51}$ should have much influence in determining the propriety of one rule as against the other. This is particularly important where the domicile is in a community property state since, on death intestate, the decedent's nnovable property will be distributed according to the law of the domicile, which will have no provision for the equivalent of dower or curtesy interests in non-community property. If movables acquired in non-community states are deemed community property by the law of the domicile, this difficulty is substantially alleviated.

It has been suggested that there is a difference between the creation of marital interests in pre-existent property by reason of marriage and the acquisition of such imterests in property acquired after marriage, in that the interests in the first case arise by operation of law whereas they arise by act of the parties in the second case. It is obvious that this is not true. ${ }^{52}$ A typical imstance of the latter sort is that in which a husband earns and receives money from a third person. Our question is as to the wife's interest in the noney. The only acts have been by the husband and the one from whom he earned and received the money. The wife's interest in the money, if any, arises altogether by operation of law. That is a respect in which any problem as to narital property in novables is different from other cases in which titles are really changed by acts of the parties concerned. But the fact that marital interests in movables owned at marriage arise by operation of law is no reason why the law of the situs should or should not govern as to what marital interests arise. The true reason why the law of the situs does not gov-

50 Other types 'of cases arising with less frequency involve the claims of attaching creditors, and the validity of sales of or contracts to sell the property. The problem also may arise in other types of cases.

51 Of course, change of domicile from one state to another may defeat the possibility of having a single law to govern the whole movable estate, if movables be acquired in the course of residence at each domicile. In the nature of things, however, there will im any case be fewer domiciles than places of acquisition, since it is normal for every person to acquire some property at his domicile, and the problem will not arise unless he has also acquired some property at a place other than his domicile. This suggests a minimum of two places of acquisition to one domicile.

52 See Harding, op. cit. supra note 3, at 869. 
ern and the law of the domicile does is that the whole body of matrimonial property is really a unit and will tend to congregate at the domicile, so that it will be convenient and desirable for purposes of administering it, litigating concerning it, and handling it generally that the interests of the spouses in it be uniforn. Exactly the same thing is true as to after-acquired movables. Matrimonial interests in them arise by operation of law, just as in property existent at marriage. That does not decide anything as to whether the law of the situs or that of the domicile should govern. Convenience of the rule in operation should be the test. That test clearly favors the long-settled weight of authority on the point.

As far as inconvenience to a state of situs not the domicile, arising from the necessity of dealing with chattels by rules of law not its own, is concerned, that inconvenience exists anyway as to movables acquired in the state by purchase with property owned in accordance with the law of the domicile of the purchaser, under the "source doctrine." And this inconvenience to the situs will be in total appreciably less than the similar inconvemience to the domicile, of having to apply the law of the sitis at the time of acquisition, in view of the previously indicated strong tendency of novables to move to the domicile. A stronger argument against the orthodox rule is that the fair expectations of bona fide purchasers and attaching creditors ${ }^{53}$ will sometimes be defeated by its operation. Such persons may act in reliance upon the appearance of property being owned subject to the matrinunial interests prescribed by the law of the place at which it is held. Of course the same objection might be made, perhaps even more frequently, to the operation of a rule allowing the law of the place of original acquisition to determine matrimonial interests, since property is often removed to places other than that at which it was originally acquired, such removal many times being to the domicile. The only practical remedy, whichever rule be followed, is suggested by the possibility of any state enacting any statute it pleases for the protection of bona fide purchasers and attaching creditors under such circumstances. ${ }^{54}$

As to choses in action, the rule that marital interests are determined by the domiciliary law is almost a practical necessity. The necessity is well-nigh absolute where the chose in action does not take the form of a specialty instrument; in such cases it is impossible to find a situs of the chose in action except by artificially saying that it is at the domicile of either the debtor or creditor. It is much more understandable and consistent with reality simply to say that the law of the domicile controls marital rights in the chose in action. Louisiana was faced

53 See note 50, supra.

54 See Note (1930) 43 HARv. I. REv. 1286. 
with this problem by reason of its statute providing that all property, movable or immovable, acquired in Louisiana by residents or nonresidents is community property. ${ }^{55}$ The court was forced to decide that this could be applicable only to tangible movables, and not to intangibles. ${ }^{56}$ Choses in action represented by specialty instruments, like stock certificates, bonds, notes and insurance policies, may be said to have a situs where the specialty is, but the undesirability of having the law of the place of acquisition determine marital interests in these is even more obvious than with tangible chattels. ${ }^{57}$

The possibility that spouses separated in fact but still married might acquire separate domiciles ${ }^{58}$ does not make the problem fundamentally more difficult. When the wife has a separate domicile, the law of her husband's domicile should not control her interests in her separate acquisitions. Marital interests in such cases should be determined by the law of the domicile of the spouse who acquires the movables in question. ${ }^{59}$

\section{Effect of Change of Domiche}

It has been held that mere removal of goods from one jurisdiction to another does not change property interests in them, and that a statute of a state to which such removal occurs, providing for such change of interest by removal, would probably be unconstitutional. ${ }^{60} \mathrm{~A}$ similar problem is whether a state can by statute declare that acquisition of a domicile in the state by one previously domiciled elsewhere shall change the character of marital ownership of the new domiciliary's goods. The question is presented by a California statute ${ }^{01}$ which undertook to equalize the operation of the law of dower and curtesy in non-community states and the law of community in California. This purpose has on the whole been defeated by decisions holding the statute un-

55 Authorities cited in note 39 , supra.

56 Williams v. Pope Mfg. Co., supra note 39 (marital interests in tort claim beld governed by domiciliary law). Accord: Justis v. Atchison, T. \& S. F. Ry. (1910) 12 Cal. App. 639, 108 Pac. 328; cf. Texas \& Pacific Ry. v. Humble (1901) 181 U. S. 57; Snashall v. Metropolitan R. R. (1890) 19 D. C. (8 Mackey) 399.

57 See Jones v. Aetna Ins. Co. (1842) 14 Conn. 501; Birmingham Waterworks Co. v. Hume, supra note 41 ; Harding, op. cit. supra note 45 , at 870 .

5s Goodrich, op. cit. supra note 1 , at 46 ; Confuict of Laws Restatement (Am. L. Inst. 1932) \$30.

59 Cf. Harding, op. cit. supra note 3 , at 876.

60 Authorities cited in note 27 , supra, and accompanying text.

61 CAI. CIv. CoDE $\$ 164$ (as amended by Cal. Stats. 1917, p. 827; ibid. 1923, p. 746): "All other property acquired after marriage by either husband or wife, or both, including real property situated in this state, and personal property wherever situated, beretofore or bereafter acquired while domiciled elsewhere, which would not have been the separate property of either if acquired while domiciled in this state, is community property ..." 
constitutional in various respects, ${ }^{62}$ including that having to do with change of domicile. ${ }^{63}$ It has been urged that these decisions, none of which deals expressly with the effect of change of domiciles as such, should be reconsidered on this point. ${ }^{64}$ Leaving aside the social merit of the results which the statute seeks to attain, it seems that its constitutionality in this particular respect necessarily turns on whether the interests of the spouses in marital property, which interests the statute seeks to affect, are to be deemed "vested rights."

Any attempt by one state to require citizens of other states to forfeit "vested rights" in property as a condition to acquiring domicile in the state is certain to run afoul of constitutional prohibitions. A citizen of California may have a domicile there without being subjected to such deprivation; in fact, any attempt thus to deprive him of "vested rights" in property would be a taking of property without due process of law. ${ }^{65}$ That being true, subjection of a non-citizen to this deprivation which could not be imposed on a citizen would clearly be in violation of the privileges and immunities clause of the Federal Constitution, ${ }^{66}$ regardless of whether or not it would violate the due process clause ${ }^{67}$ as to the non-citizen. The right of citizens of each state to go into other states and establish new homes therein comes as clearly within the scope of the privileges and inmunities clause as does any privilege guaranteed by it. It is the typical situation which the clause was designed to cover. Acquisition of a new domicile normally follows, by operation of law purely, as an incident to exercise of that guaranteed privilege. If a newcomer establishes his home in California he is by law assigned a new domicile there whether he wants it or not. ${ }^{68}$ Since acquisition of new domicile can usually occur only by reason of exercise of the constitutional privilege and represents no independent request for or grant of added privileges by the state in which domicile

62 In re Estate of Drishaus; Williams v. Sutphen; In re Bruggemeyer's Estate; Melvin v. Carl; Scott v. Remley; Latterner v. Latterner; In re Thornton's Estate, all supra note 20.

${ }^{63}$ See Note (1932) 5 So. CallF. Rev. 309, noting In re Bruggemeyer's Estate, supra note 20.

64 See Notes (1922) 10 CALIF. L. Rev. 154; (1927) 15 ibid. 399; (1932) 20 ibid. 201.

65 Cases cited in note 26, supra.

${ }^{66}$ U. S. Const., Art IV, \$2.

67 Ibid. Amend. XIV. An interesting and ingenious argument to the effect that the due process clause does not operate in this situation, where the property of a non-domiciliary is involved, is presented in Note (1927) 15 CaLIF. L. REv. 399, 407, nn. 36-37. The fault of the argument seems to lie in over-emphasis on the idea that "property" in goods exists only by grace of the law, which leads the writer to base his case on the notion that "property" in goods must be created by and exist anew under the law of each new state with which the goods have contact. It is to be feared that this refinement goes beyond the concept of "property" used by courts today in dealing with the due process clause.

68 Conflict of Laws RestateMrent (Am. L. Inst. 1932) \$17. 
is acquired, it cannot be argued that the state can exact a surrender of "vested rights" in property as a condition to allowing the new domicile.

It is of course still possible to ask whether the interests of spouses in marital property should be treated as "vested rights" at all. The question has frequently been raised, but the cases have generally answered it in the affirmative. ${ }^{69}$ Objections to this result are understandable. Should these objections be sustained, the California statute would for the most part be valid and constitutional. It seems that further attempts to have the California statute achieve its original object should be directed toward this aspect of the problem.

\section{ConcLusion}

A hypothetical case will serve to recapitulate some of the principal matters dealt with in this article. Suppose a husband and wife are domiciled in $Y$, a common law state, and that the luusband has acquired chattels there. Then they change their domicile to $X$, a conımunity property state, leaving the chattels in $Y$. The chattels remain the husband's separate property; titles will not be changed by moving a domicile across a state line any more than by moving the chattel itself across a state line. Suppose then that the old chattels are exchanged for new chattels, the new chattels still being left in state $Y$. The accepted rule is that the law of the domicile at the time of acquisition controls as to marital interests in movables. We are faced with no difficulty - the law of the donnicile will, in practically all jurisdictions, be represented in this case by the "source doctrine," to the effect that movables acquired with the husband's separate property are themselves also his separate property. The law of $X$, and that of $Y$, will agree as to what marital interests are present. But suppose that $X$ state has a statute saying that all inovables acquired by $X$ state domiciliaries, with property which lad it been acquired in $X$ would have been community property, shall be community property. There is ouly one logical rule for the solution of this case, and it produces a result as desirable as any other, in the practical sense-marital interests in movables acquired after marriage should be determined by the law of the husband's domicile at the time of the acquisition, which is state $X$, but the law of the situs, $Y$, has the power to declare that in a given case the law of the domicile slaall not control. The statute in state $X$ will control, unless the law of state $Y$ specially intervenes and asserts its own primary control over the chattel within its borders.

Robert A. Leflar.*

UNIVERSITX OF KaNSAS LAW Schoor.

69 Cases cited in notes 24-26, supra.

* The author wishes to express appreciation for valuable criticisms of parts of this paper by Prof. Joseph H. Beale in his semmar on Conflict of Laws at the Harvard Law School, and by Professor Francis W. Jacob of the University of Kansas Law School. 